\title{
KEBIJAKAN PERIZINAN LINGKUNGAN HIDUP DI DAERAH ISTIMEWA YOGYAKARTA*
}

\author{
H. Rhiti** dan Y. Sri Pudyatmoko ${ }^{* * *}$ \\ Bagian Hukum Adminstrasi Negara \\ Fakulatas Hukum Universitas Atma Jaya Yogyakarta, Yogyakarta \\ Jalan Mrican Baru 28, Yogyakarta, D.I. Yogyakarta 55281
}

\begin{abstract}
In DIY the environmental permit is recognized as an istrument for preventing the environmental problems. Local Government policies related to environmental permits are: the harmonization of economic interests with local wisdom and the environment; the interconnection between environmental permits and spatialplanning; the environmental permit as a requirement for the nuisance permit and building permit; the application of SPPL (statement letter to manage the environment) for small lactivities. According to local governments, the policies are appropriate to protect the environment.
\end{abstract}

Keywords: pollution, environment, permit.

\section{Intisari}

Di DIY perizinan lingkungan diakui sebagai instrumen untuk mencegah timbulnya masalah lingkungah hidup. Kebijakan Pemerintah Daerah terkait perizinan lingkungan dilakukan dengan: harmonisasi kepentingan ekonomi, muatan lokal dan lingkungan; mengaitkan perizinan lingkungan dan RTRW; menjadikan Izin Lingkungan sebagai syarat bagi Izin Gangguan dan IMB; dan penerapan SPPL bagi kegiatan mikro dan kecil. Kebijakan-kebijakan tesebut dianggap oleh Pemerintah Daerah sebagai cukup tepat bagi pelestarian fungsi lingkungan hidup di daerah.

Kata kunci: pencemaran, kerusakan lingkungan, izin.

\section{Pokok Muatan}

A. Latar Belakang Masalah 264

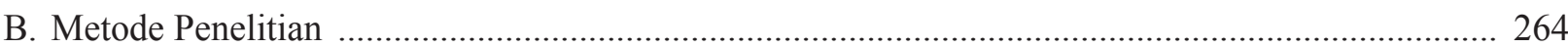

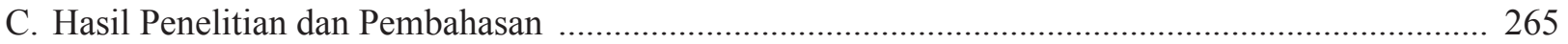

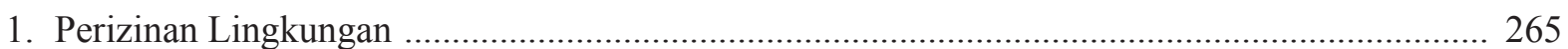

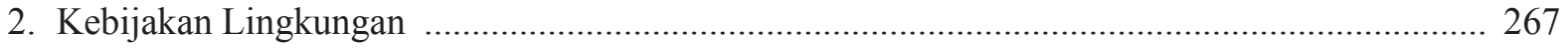

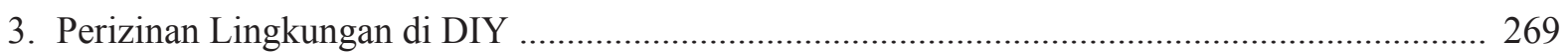

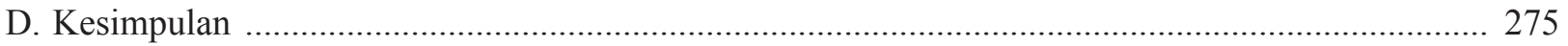

Penelitian Hibah Bersaing Dikti Tahun 2015.

** Alamat korespondensi: hyro@mail.uajy.ac.id

*** Alamat korespondensi: pudy07@gmail.com. 


\section{A. Latar Belakang Masalah}

Pencemaran, perusakan dan kerusakan lingkungan adalah masalah yang sangat serius bagi lingkungan hidup. Masalah ini juga terjadi di DIY berupa pencemaran (tanah, air, udara) dan masalah kerusakan akibat kegiatan tambang. ${ }^{1}$ Sebagaimana diketahui, DIY adalah provinsi yang memiliki karakter budaya yang sangat kuat, termasuk bidang pendidikan. Maka amat disayangkan bila kondisi lingkungan hidup di daerah ini ditandai dengan adanya pencemaran, perusakan dan kerusakan.

Salah satu upaya pencegahan pencemaran, perusakan dan kerusakan lingkungan itu adalah melalui kebijakan sistem perizinan lingkungan. ${ }^{2}$ Persoalan penting yang terkait dengan ini ada pada perizinan dan sistemnya, seperti tidak ketatnya persyaratan perizinan, penyalahgunaan dan pelanggaran izin, tidak adanya izin bagi kegiatan dan atau usaha serta tidak sinkronnya kebijakan perizinan dengan masalah lingkungan hidup di daerah yang bersangkutan. Demikian pula diandaikan, bahwa bila sistem perizinan ditetapkan berdasarkan peraturan (hukum positif) ditambah kebijakan Pemda yang berpihak kepada kepentingan lingkungan hidup (proekosistem) melalui sistem perizinannya, maka masalah pencemaran, perusakan dan kerusakan lingkungan hidup tidak akan terjadi, minimal berkurang.

Tulisan ini mencoba untuk menguraikan hal tersebut dalam suatu laporan penelitian ${ }^{3}$ yang berkaitan dengan masalah itu dengan judul: "Pencegahan Pencemaran, Perusakan dan Kerusakan Lingkungan melalui Kebijakan Sistem Perizinan di DIY" Masalah-masalah yang diangkat dalam penelitian ini berkaitan dengan sistem perizinan yang berlaku di masing-masing Kabupaten, kebijakan perizinan (dalam kaitannya dengan upaya pencegahan masalah tersebut di atas) dan kemungkinan alternatif perizinannya. Tujuan yang ingin dicapai dengan penelitian ini ialah terciptanya sistem perizinan yang terpadu, koordinatif dan ekologis.

\section{B. Metode Penelitian}

Metode penelitian yang digunakan meliputi jenis penelitian dan pendekatannya. Jenis penelitian yang digunakan adalah penelitian hukum normatif (deskriptif kualitatif), yaitu yaitu penelitian yang berkaitan dengan dokumen-dokumen hukum seperti peraturan perundang-undangan positif dan kebijakan-kebijakan pemerintah(tertulis). Sementara, pendekatannya dengan yuridis ekologis.

Penelitian normatif kualitatif berkaitan dengan sistem norma sebagai pusat kajiannya, atau tentang kaidah dan aturan. ${ }^{4}$ Dalam hal ini yang dimaksud adalah aturan-aturan mengenai perizinan lingkungan hidup (pusat dan daerah). Sementara itu yang dimaksud dengan "deskriptif kualitatif" di sini menunjuk pada sifat uraian laporan penelitian. Peneliti menyadari adanya "tegangan" atau kesenjangan antara aturan yang kaku dengan praksis dalam realita yang penuh perubahan kualitatif, ${ }^{5}$ sehingga penelitian ini tidak semata-mata positivistik, melainkan juga dengan paradigma kebijakan. Ini berkaitan dengan "Izin" sebagai "aturan" yang diasumsikan berpihak kepada kepentingan lingkungan hidup.

Pendekatan penelitian ini yuridik-ekologis, yakni bahwa perizinan berdasarkan pada aturan tetapi konteksnya adalah ekologi, yaitu hubungan antara manusia dan lingkungan hidup dalam berbagai kepentingan yang dikoordinasi secara administratif kelembangaan Pemerintah Daerah.

\section{Hasil Penelitian dan Pembahasan 1. Perizinan Lingkungan}

Menurut Spelt dan Ten Berge izin merupakan suatu persetujuan dari penguasa berdasarkan UU

\footnotetext{
Mediani Dyah Natalia, "Penambangan Pasir Bantul, Lahan Warga Tergerus", http//:harianjogya.com, diakses 28 November 2015. Takdir Rahmadi, 2011, Hukum Lingkungan di Indonesia, RajaGrafindo Persada, Jakarta, hlm. 108-111.

Penelitian yang dimaksud di sini adalah program hibah bersaing (yang disetujui DIKTI) dan telah dilakukan pada tahap I di Kabupaten Sleman, Bantul dan Kota Yogyakarta.

Mukti Fajar dan Yulianto Achmad, 2010, Dualisme Penelitian Hukum Normatif \& Empiris, Pustaka Pelajar, Yogyakarta, hlm. 36. Bdk. Anthon Susanto, 2011, Penelitian Hukum Transformatif - Partisipatoris, LoGoz Publishing, Bandung, hlm. $72-73$.
} 
atau Peraturan Pemerintah, untuk dalam keadaan tertentu menyimpang dari ketentuan larangan perundang-undangan (izin dalam arti sempit). ${ }^{6}$ Kemungkinan seseorang atau suatu pihak untuk melakukan suatu kegiatan tertentu tertutup kecuali diizinkan oleh pemerintah. Pemerintah dengan keputusan izinnya memperkenankan sesuatu yang sebetulnya tidak boleh dilakukan. ${ }^{7}$

Izin memperoleh kekuatan normatifnya hanya dari pemerintah dan karenanya juga diawasi oleh Pemerintah sebagai pemberi izin. Jadi pemerintahlah agen utama dalam hal perizinan sekaligus aktor yang berpotensi mengubah: yang tidak boleh menjadi boleh, dan yang sudah diizinkan bisa saja dicabut kembali izinnya. Suatu perbuatan atau kegiatan yang diizinkan sering dianggap sebagai perbuatan atau tindakan yang dilarang oleh aturan. Izin yang dikeluarkan untuk ini diinterpretasikan sebagai "pembolehan" terhadap perbuatan yang sebenarnya dilarang. Konotasi izin lalu menjadi negatif. Yang dimaksud adalah dilarang manakala tidak ada izinnya.

Izin juga tidak sama dengan pembiaran. Kalau ada suatu aktivitas dari anggota masyarakat yang sebenarnya dilarang oleh peraturan perundang-undangan yang berlaku, tetapi ternyata tidak dilakukan penindakan oleh aparatur yang berwenang, pembiaran seperti itu bukan berarti diizinkan. Itu adalah tindakan ilegal. Ini banyak terjadi dalam realita, meskipun akibatnya belum tentu buruk bagi lingkungan. ${ }^{8}$ Pembiaran itu bukanlah esensi izin. Untuk dapat dikatakan sebagai izin harus ada keputusan yang konstitutif dari aparatur yang berwenang menerbitkan izin. ${ }^{9}$
Menurut Spelt dan Ten Berge motif-motif untuk menggunakan sistem izin dapat berupa: keinginan mengarahkan (mengendalikan-"sturen") aktivitas-aktivitas tertentu, mencegah bahaya bagi lingkungan, keinginan melindungi obyek-obyek tertentu, hendak membagi benda-benda yang sedikit, dan pengarahan dengan menyeleksi orangorang dan aktivitas-aktivitas. ${ }^{10}$

Dalam kaitannya dengan izin di bidang lingkungan hidup, motifnya adalah untuk menjamin terlindunginya kualitas lingkungan hidup melalui pengendalian (sturen) perilaku atau aktivitasaktivitas tertentu dari masyarakat pada umumnya. Berkaitan dengan ini, Michael Kloepfer berpendapat bahwa izin lingkungan adalah alat kontrol yuridis administratif terhadap setiap kegiatan atau usaha yang di dalam peraturan perundangundangan disebutkan sebagai harus mempunyai izin. Tujuannya ialah untuk melindungi kualitas lingkungan melalui pengendalian perilaku. ${ }^{11}$ Maka izin lingkungan tidak hanya sekedar instrumen hukum berupa penetapan Pemerintah saja, melainkan yang terutama adalah perilaku.

Izin mempunyai urgensi tertentu, yaitu sebagai landasan hukum (legal base), instrumen untuk menjamin kepastian hukum, sebagai instrumen untuk melindungi kepentingan, dan sebagai alat bukti dalam hal ada klaim. ${ }^{12}$ UndangUndang Nomor 32 Tahun 2009 tentang Perlindungan dan Pengelolaan Lingkungan Hidup (UUPPLH) secara eksplisit menyebut perizinan sebagai bagian dari instrumen pencegahan pencemaran, perusakan dan kerusakan lingkungan hidup. ${ }^{13}$ Salah satunya ialah izin lingkungan yaitu "izin yang diberikan

\footnotetext{
N. M. Spelt\&J.B.J.MtenBerge, 1993,Pengantar Hukum Perizinan, Penerbit Yuridika, Surabaya, hlm. 2-3.

Fockema Andrae, 1951, Rechtsgeleerd Handwoordenboek, Uitgevers Maatshappij (NV), Groningen, hlm. $310-311$.

Anang Zakaria“Dari Ratusan Penambang Pasir di Sleman, Hanya 1 Berizin", www.tempo.com, diakses tanggal 22 September 2015.

Y.Sri Pudyatmoko, 2009, Perizinan problem dan upaya pembenahan, Grasindo, Jakarta, hlm. 8.

N. M. Spelt dan Ten Berge, Op.cit., hlm. 4.

Michael Kloepfer, 1989,Umweltrecht, C.H. Beck’sche Verlagsbuchhandlung, München, hlm. 121.

Y. Sri Pudyatmoko, Op.cit., hlm. 22-24.

Pengertian yuridis (bukan teknis) pencemaran, perusakan dan kerusakan lingkungan dinyatakan dalam UUPPLH. Pencemaran Lingkungan adalah masuk atau dimasukkannya makhluk hidup, zat, energi, dan/atau komponen lain ke dalam lingkungan hidup oleh kegiatan manusia sehingga melampaui baku mutu lingkungan hidup yang telah ditetapkan (Pasal 1 butir 14). Sementara itu Perusakan Lingkungan adalah tindakan yang menimbulkan perubahan langsung atau tidak langsung terhadap sifat fisik, kimia, dan/atau hayati lingkungan hidup sehingga melampaui kriteria baku kerusakan lingkungan hidup (Pasal 1 butir 16). Sedang Kerusakan Lingkungan Hidup adalah perubahan langsung dan/atau tidak langsung terhadap sifat fisik, kimia, dan/atau hayati lingkungan hidup yang melampaui kriteria baku kerusakan lingkungan hidup (Pasal 1 butir 17). Tolok ukur untuk menentukan adanya pencemaran adalah Baku Mutu Lingkungan (Ambien), sedang tolok ukur untuk perusakan/kerusakan adalah Kriteria Baku Kerusakan Lingkungan (KBKL). Tolak ukur ini terkait erat dengan izin.
} 
kepada setiap orang yang melakukan usaha dan/atau kegiatan yang wajib amdal atau UKL-UPL dalam rangka perlindungan dan pengelolaan lingkungan hidup sebagai prasyarat untuk memperoleh izin usaha dan/atau kegiatan." ${ }^{14}$

Pertama, setiap orang dapat memperoleh izin ini, yaitu orang perseorangan atau badan usaha, baik yang berbadan hukum maupun yang tidak berbadan hukum (Pasal 1 butir 32). Keduanya bukan pembeda dalam memperoleh izin itu, karena dianggap sama akibatnya bagi lingkungan hidup. Filosofinya ialah, setiap orang punya kepentingan yang sama atas lingkungan dan karenanya menjadi subjek bagi izin.

Kedua, izin ini diberikan tidak kepada semua usaha atau kegiatan. Hanya yang wajib memiliki AMDAL (Analisis Mengenai Dampak Lingkungan) atau yang wajib memiliki UKLUPL (Upaya Pengelolaan Lingkungan HidupUpaya Pemantauan Lingkungan Hidup ${ }^{15}$ yang wajib mempunyai izin lingkungan. Batasan yang ditentukan aturan ini cukup jelas. Tolok ukur untuk menentukan apakah suatu kegiatan wajib Amdal atau UKL-UPL ditentukan dalam Pasal 22 ayat (2) serta Pasal 34 dan 35 (yang ditindaklanjuti dengan Permen No. 5 Tahun 2012 tentang Kegitan yang Wajib Amdal dam Permen LH No. 13 Tahun 2010 tentang UKL-UPL dan SPPL).

Ketiga, izin tersebut dikaitkan dengan upaya perlindungan dan pengelolaan lingkungan hidup, bukan demi semata-mata sahnya suatu perbuatan. Dengan demikian, logis bahwa lingkungan hidup dilindungi dan dikelola juga melalui mekanisme perizinan. UUPPLH implisit menyatakan bahwa tercemar dan tidaknya atau rusak dan tidaknya lingkungan hidup tergantung pada perizinan. Berkaitan dengan ini, Siti Sundari Rangkuti menulis, bahwa kebijakan perizinan lingkungan dari Pemerintah (termasuk Pemerintah Daerah) yang kemudian tertuang dalam hukum positif (termasuk Peraturan Daerah) adalah upaya untuk mencegah terjadinya degradasi lingkungan hidup. Selengkapnya dikatakan:

Izin tertulis diberikan dalam bentuk penetapan (beschikking) penguasa. Pemberika izin yang keliru atau tidak cermat serta tidak memperhitungkan dan mempertimbangkan kepentingan lingkungan akan mengakibatkan terganggunya keseimbangan ekologis yang sulit dipulihkan. Perizinan (lingkungan) merupakan instrumen kebijakan lingkungan yang paling penting. ${ }^{16}$

Proposisi ini sebetulnya bukan hanya soal gagasan kebijakan yang lantas menjadi logika hukum lingkungan, melainkan praktek ekologis. Dengan kata lain, perizinan tidak berhenti pada sekedar kebijakan, melainkan pada konsistensi pelaksanaan dan pengawasannya. Sebab, masalah lingkungan hidup tidak diartikan sebagai disebabkan oleh semata-mata kegiatan ekonomi atau akibat teknologi maju, melainkan masalah kebijakan yang terwujud nyata dalam perilaku dan pengawasannya. Dalam hal ini, izin lingkungan bermain pada aras keputusan yang bisa fatal dan bisa juga tidak bagi lingkungan hidup. Demikian pula, bahwa izin (Genehmigung) lingkungan hidup bersifat preventif (pencegahan pencemaran, perusakan dan kerusakan lingkungan hidup) dan represif(tindakan pemerintah terhadap para pelaku usaha atau kegiatan). ${ }^{17}$

14 Pasal 1 butir 35 UUPLH (Lembaran Negara Republik Indonesia Tahun 2009 Nomor 140, Tambahan Lembaran Negara Republik Indonesia Nomor 5059) jo. Pasal 1 butir 1 PP No. 27 Tahun 2012 tentang Izin Lingkungan (Lembaran Negara Republik Indonesia Tahun 2013 Nomor 48, Tambahan Lembaran Negara Republik Indonesia Nomor 5285).

15 Pengertian AMDAL terdapat pada Pasal 1 butir 11 UUPPLH: “Analisisi Mengenai Dampak Lingkungan, yang selanjutnya disebut Amdal, adalah kajian mengenai dampak penting suatu usaha dan/atau kegiatan yang direncanakan pada lingkungan hidup yang diperlukan bagi proses pengambilan keputusan tentang penyelenggaraan usaha dan/atau kegiatan." Jadi Amdal adalah suatu kajian ilmiah ekologis (environmentalimpactassessment) yang hasilnya dipakai untuk menentukan apakah suatu kegiatan atau usaha diizinkan atau tidak sesuai dengan dampaknya. Lihat John Glasson, et al., Introductionto Environmental Impact Assessment (3trd Edition), UCL Press, London, 1994, hlm..1,26-27.. Semenara itu yang dimaksud dengan UKL-UPL ialah "Pengelolaan dan pemantauan terhadap usaha dan/atau kegiatan yang tidak berdampak penting terhadap lingkungan hidup yang diperlukan bagi proses pengambilan keputusan tentang penyelenggaraan usaha dan/ atau kegiatan" (Pasal 1 butir 12).

16 Siti Sundari Rangkuti, 1987, Hukum Lingkungan dan Kebijakan Lingkungan Dalam Proses Pembangunan Nasional Indonesia, Disertasi, Universitas Airlangga, Surabaya, hlm. 93.

17 Reiner Schmidt, 1992, Einführungin das Umweltrecht (Pengantar Hukum Lingkungan), VerlagC.H.Beck, München, hlm. 11. 
Keempat, dari pengertian izin lingkungan di atas yang juga penting ialah bahwa izin lingkungan sendiri merupakan syarat pemberian izin usaha. Dengan demikian izin lingkungan bukan izin terakhir, melainkan "izin syarat" bagi izin usaha. Usaha yang diberikan izinnya diasumsikan sebagai usaha legal dan terutama tidak mencemari atau merusak lingkungan, karena didahului dengan kajian AMDAL atau UKL-UPL. Jika dilihat dari urut-urutannya, maka pertama-tama dari AMDAL atau UKL-UPL kemudian keputusan kelayakan lingkungan (Pasal 31 jo. Pasal 36 ayat (2)), izin lingkungan dan izin usaha.

Selain izin lingkungan ada pula izin-izin lain seperti HO, IMB, Izin Usaha Industri, Izin Lokasi, Izin Usaha Pertambangan, Izin Pemanfaatan Hasil Hutan, Izin Pembuangan Limbah, termasuk Bahan Beracun dan Berbahaya (B3) dan lain-lain. Pada masa berlakunya UU No. 23 Tahun 1997 (UUPLH), semua izin ini termasuk dalam kategori "perizinan lingkungan." Ketika itu tidak ada izin lingkungan sebagai nama dari izin tersendiri. Kini dalam UUPPLH ada "Izin Lingkungan" yang berbeda dari izin-izin yang disebutkan itu. Meskipun demikian, semua izin tersebut-meskipun tidak disebut sebagai "Izin lingkungan" berhubungan erat dengan izin lingkungan.

\section{Kebijakan Lingkungan}

Kebijakan lingkungan yang dimaksud di sini terdiri dari kebijakan lingkungan secara umum dan bidang perizinan lingkungan. Kebijakan (policy) secara leksikal adalah: a) a guiding principle or course of action adopted toward an objective or objectives; dan b) prudence or practical wisdom. ${ }^{18}$ Berdasar arti kamus itu, maka kebijakan adalah "prinsip atau pedoman bagi tindakan yang mempunyai tujuan tertentu. Kebijakan lingkungan hidup termasuk dalam kebijakan publik ekologis, karena menyangkut kepentingan umum (bukan hanya kepentingan Pemerintah dan Pengusaha). Secara teoretis, kebijakan publik berhubungan dengan apa yang dipilih Pemerintah untuk dilakukan (juga tidak dilakukan), mengapa seperti itu, dan apakah ada perbedaan yang ditimbulkannya. ${ }^{19}$ Menurut Harold D. Lesswell dan Abaraham Kaplan, kebijakan adalah "a projected program of goal, values and practices". ${ }^{20}$ Ketika Pemerintah membuat kebijakan lingkungan misalnya, tentu ada maksud dan tujuan yang hendak dicapai dengan menjunjung tinggi nilai-nilai kelestarian fungsi ekologis bagi kemaslahatan bersama.

Sementara itu, menurut Carl Joachim Friedrick kebijakan adalah "serangkaian tindakan yang disusulkan oleh seseorang, kelompok atau pemerintah dalam suatu lingkungan tertentu dengan menunjukkan hambatan-hambatan dan kesempatan-kesempatan terhadap pelaksanaan usulan kebijakan tersebut dalam rangka mencapai tujuan tertentu"21 Istilah yang dipakai dalam tulisan ini adalah kebijakan (policy), bukan kebijaksanaan. Sebagaimana disinggung di atas, konteks kebijakan di sini adalah kebijakan Pemerintah (yang dalam literatur disebut juga dengan istilah "kebijakan negara"). Tulisan ini menggunakan istilah "kebijakan Pemerintah" untuk menunjuk subjek yang membuat kebijakan, bukan seluruh unsur negara.

Dalam demokrasi modern, kebijakan Pemerintah tidak hanya berisi cetusan pikiran atau pendapat pejabat yang mewakili rakyat, tetapi juga berkaitan dengan opini publik. Dengan demikian, kebijakan Pemerintah juga harus dapat melayani kepentingan publik (umum)"'22 Ini sesuai pula dengan pendapat yang menyatakan, bahwa pembuatan kebijakan senantiasa dilandasi oleh keinginan masyarakat (reconciliation dan crystalization of

\footnotetext{
18 Webster's Desk Dictionary of the English Languange, Potland House, New York, 1990, hlm. 700.

19 Thomas R. Dye, 1978, Understanding Public Policy, Engelwood Clifs, New York, hlm. 3, sebagaimana dikutip oleh Siti Sundari Rangkuti, op.cit., hlm. 71 .

20 Harold D. Lasswell and abeaham Kaplan, 1970, Power and Society, Yale University Press, New Haven, hlm. 70-71.

21 CJ. Friedrick, 1963, Man and His Government, Mc. Graw Hill, New York, hlm.39 sebagaimana dikutip oleh M. Irfan Islamy, 1992, Prinsipprinsip Perumusan Kebijaksanaan Negara, Bumi Aksara, Jakarta, hlm. 17.

22 M. Irfan Islamy, Ibid., hlm. 10.
} 
the views and wants of many people and groups in the body of social). ${ }^{23}$ Benar, bahwa dalam alam demokrasi keinginan atau aspirasi masyarakat harus diakomodasi, sehingga kebijakan bersifat komunal.

Kebijakan Pemerintah adalah kebijakan yang diciptakan atau dibuat oleh lembaga-lembaga dan pejabat-pejabat pemerintah. Menurut George C. Edward III dan Ira Sharkansky, kebijakan Pemerintah adalah apa yang dinyatakan dan dilakukan atau tidak dilakukan oleh pemerintah. Kebijakan negara itu berupa sasaran atau tujuan program-program pemerintah" ${ }^{24}$ Dikaitkan dengan lingkungan hidup, kebijakan itu berorientasi pada tujuan pengelolaan dan perlindungan lingkungan hidup.

Selanjutnya menurut J.E. Anderson, implikasi dari pengertian kebijakan Pemerintah adalah: Pertama, kebijakan berorientasi pada tujuan. Dalam konteks lingkungan hidup, jelas tujuannya ialah pelestarian fungsi lingkungan hidup.

Kedua, kebijakan berisi pola tindakan Pemerintah. Ketiga, kebijakan itu adalah hal yang dilakukan secara konsekuen oleh Pemerintah, bukan rencana Pemerintah untuk melakukan sesuatu. Keempat, kebijakan Pemerintah harus bersifat positif, yaitu dalam rangka mengatasi permasalahan tertentu. Ini berkaitan dengan keputusan Pemerintah mengenai tidak diizinkannya sesuatu karena pertimbangan tertentu, seperti adanya bahaya bagi keselamatan, mengganggu ketertiban/keamanan atau merugikan lingkungan hidup. Kelima, kebijakan Pemerintah dilandaskan pada peraturan perundang-undangan (hukum positif) yang berlaku. ${ }^{25}$

Kebijakan lingkungan mengikuti teori seperti disebutkan. Pertama, Pemerintah secara nasional mengadopsi konsep global mengenai pembangunan berkelanjutan (sustainable development) yang berwawasan lingkungan dan dimasukkan juga sebagai ketentuan UU, yaitu tentang Kajian Lingkungan Hidup Strategis/KLHS (Pasal 15 UUPPLH jo. Permen LH No. 9 Tahun 2011). Menurut ketentuan UU, KLHS wajib dibuat oleh Pemerintah dan Pemerintah Daerah dan dimasukkan ke dalam penyusunan Rencana Tata Ruang Wilayah (RTRW), Rencana Pembangunan Jangka Panjang (RPJP) dan Rencana Pembangunan Jangka Menengah (RPJP) Provinsi, Kabupaten dan Kota. Dengan demikian dari sisi performatif dan normatif kebijakan Pemerintah adalah melalui KLHS ini.

Tujuan dari kebijakan tersebut ialah untuk mencegah terjadinya pencemaran, perusakan dan kerusakan lingkungan hidup. Dalam ketentuan KLHS disebutkan mengenai perhatian Pemerintah Daerah terhadap ekosistem (daerah yang bersangkutan). Selain itu, dalam melakukan kajian, pemerintah harus menggunakan prinsip-prinsip seperti kehati-hatian (precautionary principle). Ini adalah prinsip penting yang berarti bahwa Pemerintah Daerah harus cermat dan hati-hati dalam mengeluarkan kebijakan perizinan bagi suatu kegiatan atau usaha. Contohnya seperti di Kabupaten Sleman. Pemerintah setempat tidak tergesa-gesa mencabut larangan penambangan pasir misalnya karena desakan warga, sebab dampaknya bisa merugikan lingkungan. Termasuk kebijakan di sini ialah, ketika Pemerintah Daerah ragu-ragu atau tidak memiliki kepastian akan dampak dari suatu kegiatan atau usaha, maka pilihannya ialah "tidak buru-buru" mengeluarkan izin.

Di samping itu ada pula prinsip selfassesment (penilaian diri sendiri) atau sadar akan lingkungan. Yang dimaksud adalah kesadaran akan daya tampung dan daya dukung lingkungan ${ }^{26}$ (berdasarkan data akurat dari Pemerintah).

23 Pendapat Dimock sebagaimana dikutip oleh H.M. Hadin Muhjad, 2015, Hukum Lingkungan. Sebuah Pengantar untuk Konteks Indonesia, Genta Publishing, Yogyakarta, hlm. 11.

24 George C. Edward III dan Ira Sharkansky, 1978, The Policy Predicamment, W.H. Freeman and Company, San Farncisco, hlm. 2. Pengertian kebijakan negara itu mirip dengan yang dikemukakan oleh Thomas R. Dye, UnderstandingPublicPolicy, 1978, Prencite Hall Inc, New York, hlm. 3., sebagaimana dikutip oleh M. Irfan Islamy, Op.cit., hlm. 18.

25 M. Irfan Islamy, Op.cit., hlm. 19.

26 Pengertian daya tampung ada pada Pasal 1 angka 8 UUPPLH: "kemampuan lingkungan hidup untuk menyerap zat, energy, dan/atau komponen lain yang masuk atau dimasukkan ke dalamnya. Sedang daya dukung ialah kemampuan lingkungan hidup untuk mendukung perikehidupan manusia, makhluk hidup lain, dan keseimbangan antar keduanya (Pasal 1 angka 7). 
Kedua, kebijakan Pemerintah di bidang lingkungan hidup, khususnya di sini adalah Pemerintah Daerah, mengacu kepada ketentuan UUPPLH. Pasal 63 ayat (3) UU ini menyatakan, bahwa dalam perlindungan dan pengelolaan lingkungan hidup, Pemerintah Kabupaten/Kota memiliki beberapa kewenangan, antara lain adalah: menetapkan kebijakan tingkat kabupaten/kota; menetapkan dan melaksanakan KLHS tingkat kabupaten/kota dan menetapkan serta melaksanakan kebijakan mengenai Rencana Perlindungan dan Penglolaan Lingkungan Hidup (RPPLH) kabupaten/ kota.

\section{Perizinan Lingkungan di DIY}

Hanya dua kabupaten (Sleman dan Bantul) serta Kota Yogyakarta yang diteliti. Uraian pada bagian ini dibuat secara singkat, yaitu yang berkaitan dengan pencegahan pencemaran, perusakan dan kerusakan lingkungan melalui kebijakan sistem perizinan lingkungan. Yang dimaksud dengan "pencegahan" di sini bukan upaya yang bersifat teknis, melainkan yuridis normatif melalui sistem perizinan dan kebijakan yang dibuat oleh Pemerintah dari masing-masing daerah yang bersangkutan.

Pertama, secara umum yang dimaksud dengan pencemaran, perusakan dan kerusakan lingkungan di Kabupaten Sleman, Bantul dan Kota Yogyakarta mengacu pada batasan pengertian menurut UUPPLH. Ringkasnya, ada unsurunsur tertentu seperti limbah yang memberikan tekanan bagi lingkungan hidup. Ukuran terjadinya pencemaran dan kerusakan lingkungan itu mengacu pada ketentuan nasional dan daerah yang bersangkutan yaitu Baku Mutu Lingkungan (BML) dan Kritera Baku Kerusakan Lingkungan (KBKL) yang diatur dengan Peraturan Gubernur. Sebagai contoh, Pergub No. 7 Tahun 2010 tentang Baku Mutu Limbah Cair Bagi Kegiatan Industri, Pelayanan Kesehatan, Dan Jasa Pariwisata, Pergub No. 20 Tahun 2008 tentang Baku Mutu Air (Ambien) di DIY.

Sementara itu, tentang kondisi lingkungan hidup di masing-masing daerah dilaporkan dalam Data dan Laporan Status Lingkungan
Hidup Daerah (SLHD) Kabupaten dan Kota yang bersangkutan. Secara umum dalam pada data dan laporan itu terlihat, bahwa ada tekanan terhadap lingkungan hidup seperti dari komponen-komponen pemukiman, pertanian, pertambangan, energi, industri, pariwisata (termasuk pembangunan hotelhotel dan mall, serta Limbah B3 (Bahan Beracun dan Berbahaya). Ini berarti, bahwa potensi ancaman terhadap lingkungan hidup di masing-masing wilayah itu ada dan boleh dikatakan cukup besar. Dalam data dan laporan SLHD masing-masing daerah tersebut dikemukakan upaya pengelolaan lingkungan yang terkait dengan tekanan-tekanan terhadap lingkungan hidup antara lain melalui penegakan hukum dan dokumen lingkungan.

Penegakan hukum di Kabupaten Sleman dilakukan melalui pembuatan regulasi, penguatan kelembagaan, penerapan dokumen pengelolaan lingkungan hidup dalam proses perizinan, pendidikan mengenai lingkungan hidup, pengawasan dan penerapan sanksi (administratif) terhadap para pelaku pelanggaran. Kesadaran hukum masyarakat terlihat dari beberapa kasus (lebih 30 kasus selama 2014 s.d. pertengahan 2015). Diantara kasuskasus itu termasuk kasus pembangunan hotel yang berizin namun berkonflik dengan sebagian warga masyarakat. Sementara itu penerapan dokumen lingkungan sebagian besar adalah dokumen UKLUPL untuk kegiatan yang tidak wajib AMDAL dan pengawasan terhadap kegiatan-kegiatan tersebut. Beberapa kegiatan dan atau usaha di kabupaten ini memiliki AMDAL dan Izin Lingkungan, diantaranya seperti pengembangan RS JIH, Jogya City Mall, Hotel Marriot, dan Condotel Graha Indoland. Hasil pengawasan menunjukkan sebagian besar kegiatan yang memiliki Izin Lingkungan telah memenuhi standar Baku Mutu Lingkungan, terutama soal limbah cair.

Sementara untuk Kabupaten Bantul, upaya untuk mencegah pencemaran, perusakan dan kerusakan lingkungan akibat tekanan terhadap lingkungan hidup sebagaimana disebutkan di atas terutama melalui penyelesaian kasus-kasus dugaan adanya pencemaran akibat tumpukan sampah, 
pencemaran air dan udara. Sepanjang tahun 2014 kasus-kasus itu diselesaikan dengan baik (sumber pencemaran itu ditiadakan). Sedang untuk dokumen lingkungan hidup yang berkaitan dengan perizinan lingkungan hidup adalah AMDAL, UKL dan UPL. Selain itu ada juga dukumen Surat Pernyataan Pengelolaan Lingkungan (SPPL) yang diperuntukkan bagi usaha dan atau kegiatan yang tidak wajib memiliki AMDAL atau UKL-UPL.

Khusus untuk SPPL ini adalah sesuai dengan ketentuan UUPPLH (Pasal 35), yaitu bagi kegiatan atau usaha yang tidak wajib UKL-UPL wajib SPPL. Terlepas dari formalitas dalam hukum positif ini, yang jelas kebijakan yang diambil untuk SPPL ini penting bagi pelestarian fungsi lingkungan hidup di daerah. Ini karena justru kegiatan usaha mikro dan kecil yang ada di tengah masyarakat jauh lebih banyak daripada kegiatan-kegiatan besar yang membutuhkan AMDAL atau UKLUPL. Masyarakat sering beranggapan bahwa yang menyebabkan terjadinya pencemaran atau kerusakan lingkungan adalah kegiatan-kegiatan atau usaha yang berskala besar. Padahal, kenyataannya justru masalah lingkungan hidup itu juga disebabkan oleh kegiatan-kegiatan masyarakat yang mikro dan kecil itu. Maka kebijakan SPPL tersebut tepat bagi upaya pelestarian fungsi lingkungan hidup di daerah yang bersangkutan yang berorientasi ke masa depan. Meskipun SPPL ini bukan sejenis izin, namun "bernuansa izin", karena diwajibkan untuk kegiatan mikro dan kecil. Jadi logika hukumnya, kegiatan atau usaha mikro dan kecil ini pun kemudian tidak diperbolehkan, jika tidak ada SPPL-nya.

Dalam konteks Kota Yogyakarta juga hampir sama dengan Kabupaten Sleman dan Bantul. Pengelolaan lingkungan dilakukan melalui beberapa kegiatan seperti rehabilitasi lingkungan, dokumen lingkungan dan penegakan hukum. Mengenai penegakan hukum di wilayah Kota Yogyakarta disebutkan sebagai upaya untuk melindungi masyarakat dari bahaya pencemaran dan kerusakan lingkungan. Ini karena masyarakat mempunyai hak dan peran untuk mengajukan pengaduan mengenai dugaan adanya pencemaran dan perusakan dan kerusakan lingkugan hidup. Sementara itu, dokumen lingkungan hidup seperti AMDAL, UKL dan SPPL diberlakukan juga di daerah ini.

Dari data dan laporan ketiga daerah ini dapat dikatakan, bahwa meskipun dampak negatif bagi lingkungan hidup lebih sedikit daripada yang positif, tetap ada potensi ancaman atau tekanan bagi lingkungan hidup. Di samping itu, penegakan hukum melalui kewajiban pembuatan dokumendokumen lingkungan seperti AMDAL, UKL-UPL (sebagai syarat diberikannya Izin Lingkungan) dan SPPL telah berjalan, namun dibutuhkan pengawasan yang memadai terhadap pelaksanaan kewajiban seperti tertera dalam dokumen-dokumen itu. Selain itu, terhadap ancaman bagi lingkungan hidup diperlukan perizinan yang diandaikan dapat mencegah terwujudnya ancaman bagi lingkungan hidup.

Kedua, Pemerintah pada masing-masing wilayah itu mengakui, bahwa perizinan lingkungan adalah instrumen yang efektif bagi pencegahan masalah-masalah lingkungan tersebut. Meskipun demikian, diakui pula, bahwa masalah perizinan termasuk cukup rumit dan "berat" di masing-masing daerah. Bukan hanya mengenai masalah kegiatan yang tidak ada izinnya, melainkan juga proses perizinan itu sendiri dengan semua syarat yang harus dipenuhi dinilai cukup panjang dan "memberatkan" pihak pemohon izin. Maka efektivitas perizinan tergantung juga pada kebijakan perizinan itu sendiri.

Tentang kebijakan perizinan lingkungan di masing-masing daerah secara singkat dan deskriptif sebagai berikut. Untuk Kabupaten Sleman, landasan hukum pemberian izin adalah ketentuan hukum positif (tingkat nasional dan daerah). Pemerintah Daerah melalui Bagian Hukum membuat regulasi-regulasi perizinan sebagai landasan hukum pemberian izin. Tujuan pembuatan regulasi di bidang lingkungan hidup di daerah ini antara adalah: melindungi wilayah daerah dari pencemaran dan/atau kerusakan lingkungan hidup; mengendalikan pemanfaatan sumber daya alam secara bijaksana; menjamin keselamatan, kesehatan, dan kehidupan masyarakat Daerah; 
menjamin kelangsungan kehidupan makhluk hidup dan kelestarian ekosistem; menjaga kelestarian fungsi lingkungan terutama sebagai kawasan resapan air; mengantisipasi dampak perubahan iklim; menjamin pemenuhan dan pelindungan hak atas lingkungan hidup sebagai bagian dari HAM; mewujudkan pembangunan berkelanjutan; serta menjamin terpenuhinya kelestarian lingkungan hidup demi generasi masa kini dan masa depan.

Dilihat dari tujuan-tujuan normatif tersebut, sejatinya Pemerintah Daerah memiliki misi yang jelas bagi pelestarian fungsi lingkungan hidup di daerah. Salah satunya, melindungi lingkungan hidup daerah dari bahaya pencemaran, perusakan dan kerusakan lingkungan hidup yang ancamanancamannya sebagaimana dalam SHLD. Manfaat dan tujuan dari regulasi juga jelas, yaitu pengendali perilaku dalam konteks ekologis.

Dalam Peraturan Bupati Sleman No. 24 Tahun 2014 tentang Kewenangan Penyelenggaraan Perizinan disebutkan bahwa izin adalah "dokumen yang dikeluarkan oleh pemerintah daerah berdasarkan peraturan daerah atau peraturan bupati yang merupakan bukti legalitas, menyatakan sah atau diperbolehkannya seseorang atau badan untuk melakukan usaha atau kegiatan tertentu" (Pasal 1 angka 7). Dengan demikian, dasar pemberian izin adalah peraturan, dan izin merupakan alat bukti legalitas suatu perbuatan. Di sini memang tidak disebutkan tujuan pemberian izin itu. Namun dalam konteks pencegahan pencemaran, perusakan dan kerusakan lingkungan, izin harus juga dibaca dalam kaitannya dengan hal itu. Dengan demikian izin tidak sekedar bukti legalnya suatu perbuatan, melainkan juga memiliki tujuan ekologis.

Terkait dengan perizinan di bidang lingkungan hidup, disebutkan, bahwa Organisasi Pemerintah Daerah yang berwenang mengeluarkan izin-izin tersebut adalah Badan Lingkungan Hidup (BLH) Kabupaten. Badan ini mengurusi perizinan di luar perizinan yang diurusi oleh Badan Penanaman Modal dan Pelayanan Perizinan Terpadu (BPMPPT), meliputi Izin Lingkungan, Izin Pembuangan Air Limbah, Izin Penyimpanan
Sementara Limbah Bahan Berbahaya dan Beracun, Izin Pengumpulan Limbah Bahan Berbahaya dan Beracun, Izin Pemanfaatan Air Limbah untuk Aplikasi ke Tanah, Izin Penebangan Pohon; dan Izin Sambungan Rumah Air Limbah (lampiran Perbub). SPPL tidak (belum) disebutkan dalam peraturan tersebut sebagai bagian dari kewenangan BLH, karena SPPL bukan sejenis izin tersendiri, melainkan "Surat Pernyataan" dari pelaku usaha mikro dan kecil. Bagaimana pun, seperti disebutkan di depan, bahwa justeru masalah tekanan terhadap lingkungan hidup juga disebabkan oleh kegiatan atau usaha yang berskala mikro dan kecil, sehingga wajib memiliki SPPL. Sementara itu ada izin lain yang berkaitan langsung dengan lingkungan hidup, namun tidak dikeluarkan oleh BLH adalah perizinan di bidang pengambilan air tanah dan Izin Pertambangan Rakyat. Izinizin ini menjadi kewenangan Dinas Sumber Daya Air, Energi dan Mineral. Demikian pula dengan IMB (selain yang dilimpahkan kepada Camat) dan HO (selain yang dilimpahkan kepada Camat) serta Izin Usaha Industri (IUP) tidak dikeluarkan oleh BLH melainkan oleh BPMPPT.Lembaga ini juga berwenang mengeluarkan Izin Peruntukan Penggunaan Tanah dan Keterangan mengenai Tata Bangunan dan Lingkungan. Sementara itu izin-izin yang lain yang sebetulnya terkait dengan lingkungan hidup dan kesehatan tidak dikeluarkan oleh BLH, melainkan oleh dinas lain seperti Dinas Kesehatan. Hal penting bagi lingkungan hidup seperti KLHS (Kajian Lingkungan Hidup Strategis) tidak ditangani oleh BLH melainkan oleh DPU (Dinas Pekerjaan Umum).

Dari jenis-jenis izin dengan masing-masing instansi yang mengeluarkannya dapat dikatakan bahwa: Pertama, ada izin-izin yang berkaitan dengan lingkungan hidup dan yang terutama adalah Izin Lingkungan, di samping izin-izin lain yang terkait seperti perizinan limbah dan B3. Kedua, pelayanan perizinan bidang lingkungan hidup tidak terpadu atau bukan di bawah "satu atap." Masingmasing instansi teknis (SKPD) sesuai dengan kewenangannya mengeluarkan masing-masing 
izin. Ide dasar bahwa kepentingan lingkungan hidup ditangani oleh satu lembaga saja memang tidak dapat terwujud. Ketiga, sebagai konsekuensi instansional tentang kewenangan perizinan itu adalah koordinasi di bidang perizinan antara lembaga terkait. Koordinasi secara administratif adalah pelaksanaan wewenang yang bersifat mandiri, bukan keterpaduan. Keterpaduan terjadi, jika wewenang perizinan lingkungan berada di satu tangan atau satu lembaga. Dalam prakteknya keterpaduan ini tidak ada. Keempat, kelemahan dari tidak adanya keterpaduan perizinan lingkungan ialah kemungkinan terjadinya perbedaan kepentingan antara masing-masing lembaga menyangkut lingkungan hidup.

Kebijakan yang diambil Pemerintah Kabupaten Sleman pertama-pertama "konsekuen" dengan peraturan yang telah ada. Artinya, seperti yang diatur, lembaga-lembaga tersebut sesuai kewenangan dan regulasi secara mekanis mengeluarkan izin. Tidak ada masalah perizinan sejauh ada kelengkapan syarat dan administrasi yang dipenuhi pemohon serta instansi bekerja sesuai dengan rule-nya. Walau demikian, Pemerintah Daerah (melalui Bappeda) tetap mengambil kebijakan umum tentang lingkungan hidup, yaitu bahwa harus ada "keseimbangan" antara kepentingan ekonomi dan pelestarian fungsi lingkungan hidup. Maka dalam pemberian izin-izin yang berkaitan dengan lingkungan hidup harus ada pertimbangan sisi ekonomisnya. Di samping itu, Pemerintah Kabupaten Sleman berpendapat, bahwa dalam pemberian izin-izin tersebut harus mengacu pada RTRW sebagaimana diatur dalam Perda No. 12 Tahun 2012. Kelemahannya ialah bahwa RTRW bisa berubah. Maka ruang yang ditetapkan untuk persawahan misalnya bisa diubah menjadi kawasan pemukiman atau untuk kawasan bisnis. Izin lalu mengikuti hal ini.

Kabupaten Bantul hampir sama dengan Kabupaten Sleman dalam hal dasar pemberian izin-izin, khususnya bidang lingkungan hidup, yakni melakui regulasi yang ditetapkan pemerintah. Seperti di Kabupaten Sleman, di Kabupaten
Bantul pembangunan yang berkaitan dengan lingkungan hidup ditetapkan secara umum dalam RPJM Kabupaten Bantul (Perda No. 5 Tahun 2014.). Dalam misi yang ke IV disebutkan adanya kewaspadaan terhadap risiko bencana dengan memperhatikan penataan ruang dan pelestarian lingkungan. Salah satu tujuannya adalah meningkatkan kualitas lingkungan dan pengelolaan sumber daya alam, termasuk sumber daya hutan. Dalam Perda tersebut disebutkan program pembangunan bidang lingkungan hidup antara lain: perencanaan tata ruang (Perda No. 4 Tahun 2011 tentang RTRW), pengendalian pemanfaatan ruang, pengelolaan limbah, konservasi sungai, sumber daya air, pengelolaan persampahan dan air limbah, pengendalian polusi, kebijakan ruang terbuka hijau, pengelolaan hutan dan pertambangan. Secara umum Pemerintah Kabupaten Bantul menyatakan, bahwa kondisi lingkungan hidup di daerah ini "baik", karena telah melampaui target dalam RPJM, yaitu dengan angka indeks lingkungan hidup 72,5, melampaui angka indeks 63 sebagaimana ditargetkan dalam RPJM daerah ini.

Meskipun dikatakan "baik", dalam rangka terus melindungi kualitas lingkungan, terutama untuk mencegah terjadinya pencemaran, perusakan dan kerusakan lingkungan hidup, Pemerintah Kabupaten Bantul (melalui Bagian Hukum) telah mengeluarkan beberapa peraturan tentang perizinan, misalnya Peraturan Bupati Bantul No. 18 Tahun 2012 tentang Upaya Pengelolaan Lingkungan Hidup dan Upaya Pemantauan Lingkungan Hidup (UKL-UPL) dan Surat Pernyataan Kesanggupan Pengelolaan dan Pemantauan Lingkungan Hidup (SPPL). Kemudian Peraturan Bupati (Perbup) No. 9 Tahun 2014 tentang Izin Gangguan, Perbup No. 46 Tahun 2014 tentang Izin Lingkungan dan Perbup No. 20 Tahun 2015 tentang Izin Gangguan.

Dilihat dari regulasi-regulasi tersebut, sebetulnya secara normatif lingkungan hidup di daerah ini cukup dilindungi, sebab peraturanperaturan tersebut dengan cukup jelas menyebutkan adanya upaya perlindungan lingkungan hidup melalui mekanisme perizinan. Hanya saja 
dalam prakteknya, seperti di Sleman misalnya, kewenangan perizinan tidak berada di satu lembaga, melainkan ada di dinas-dinas (SKPD) tertentu. Dengan demikian, praktek pelaksanaan perizinan oleh instansi-instansi dilakukan secara koordinatif.

Untuk izin-izin yang berkaitan dengan lingkungan hidup misalnya, diurus dan dikeluarkan oleh Badan Lingkungan (BLH). Misalnya Izin Lingkungan yang prosesnya melalui pembuatan AMDAL, UKL-UPL menjadi kewenangan BLH. Demikian pula dengan perizinan limbah, pengolahan sampah dan SPPL ditetapkan oleh BLH. Sementara itu seperti HO dan IMB misalnya dikeluarkan oleh Dinas Perizinan. Dinas ini, meskipun bukan sebagai pihak pembuat kebijakan,menangani izin-izin yang menjadi kewenangannya. Di antara izin-izin yang berkaitan dengan lingkungan hidup selain $\mathrm{HO}$ dan IMB tersebut, adalah Izin Lokasi, Izin Usaha Industri (IUI), Izin Perluasan Industri, Izin Pemakaian Air Tanah (sumur gali, bor dan mata air), dan Izin Eksplorasi dan Pengeboran Air Tanah. Menurut data per Januari-Juni 2015, jumlah pemohon izin yang terbanyak adalah HO dan IMB. Dengan demikian dari segi jumlah pemohon, kesadaran akan pentingnya perizinan tersebut bagi lingkungan hidup dapat dikatakan cukup tinggi. Harapannya ialah bahwa dengan izin-izin itu pelestarian fungsi lingkungan hidup tetap terjamin.

Berkaitan dengan perizinan lingkungan hidup, peran BLH memang sangat penting. Meskipun bukan sebagai pembuat kebijakan, BLH Kabupaten Bantul dalam melaksanakan tugas dan wewenangnya senantiasa memberi masukan berharga bagi pemerintah terutama ketika membuat regulasi terkait lingkungan hidup di daerah. Selain itu, BLH melakukan pengawasan dan kerja sama atau koordinasi dengan dengan instansi lain, termasuk dengan pihak provinsi untuk izin dari provinsi seperti eksplorasi dan eksploitasi pasir di sungai. Tugas BLH adalah membina dan menilai kegiatan sejauh berhubungan dengan izin dan lingkungan hidup. Di samping itu -menurut BLH- untuk mencegah atau mengatasi persoalan lingkungan hidup diperlukan langkah pemberdayaan masyarakat agar masyarakat mengetahui arti pentingnya lingkungan hidup. Di sini lingkungan hidup bukan hanya lingkungan hidup fisik, melainkan juga lingkungan sosial budaya. Menyangkut lingkungan ini, Pemerintah Kabupaten Bantul tidak mengizinkan pendirian mall dan diskotik karena akan "mengganggu moral" masyarakat.

Seperti di Sleman, salah satu kebijakan yang diambil mengenai izin-izin tersebut ialah bahwa perizinan (khususnya pemberian izin) dikaitkan dengan ketentuan RTRW (Perda No. 12 Tahun 2012). Ruang memang penting dan berhubungan erat dengan lingkungan hidup, sehingga berbagai kebijakan yang terkait lingkungan hidup daerah, termasuk perizinan, dikaitkan dengan ruang. Secara yuridis sistematik tentang hal ini tidak disebutkan dalam aturan nasional seperti UUPPLH. Yang dinyatakan dalam UU ini hanyalah bahwa KLHS yang dibuat oleh Pemerintah Daerah diintegrasikan ke dalam program pembangunan daerah dan tata ruang. Bahwa perizinan dikaitkan dengan RTRW adalah sebuah kebijakan yang diambil oleh pemerintah setempat. Tujuan yang hendak dicapai dengan kebijakan ini selain peruntukan ruang tidak dilanggar, juga dengan adanya izin diandaikan tidak akan terjadi pencemaran, perusakan dan kerusakan lingkungan hidup di "ruang” yang bersangkutan.

Di samping kebijakan itu ada pula kebijakan pemerintah tentang Izin Lingkungan. Izin ini ternyata bukan izin terakhir atau seperti dalam UUPPLH- sebagai syarat pemberian Izin Usaha, melainkan sebagai salah satu syarat (ditambah SPPL) pemberian IMB dan HO. Kebijakan ini menjadi bagian dari regulasi, yaitu dinyatakan dalam Perda No. 9 Tahun 2014 tentang Izin Gangguan (Pasal 5 ayat (1) huruf e). Demikian pengertian gangguan diperluas menjadi masalah fisik lingkungan hidup, seperti ancaman pencemaran, perusakan dan kerusakan lingkungan hidup. Selain kebijakan itu, diambil pula kebijakan lain, yaitu mempermudah proses pengurusan izin. Bahkan Izin Lingkungan "dapat diganti" dengan HO saja, karena izin tersebut adalah bagian "kecil" dari HO. Kebijakan ini meskipun "tidak sejalan dengan UUPPLH", 
tetap merupakan sebuah upaya pelestarian fungsi lingkungan hidup yang diambil oleh Pemerintah Daerah.

Selanjutnya, kebijakan perizinan di wilayah Kota Yogyakarta. Seperti di Kabupaten Sleman dan Bantul, pengaturan perizinan lingkungan hidup di wilayah kota adalah melalui regulasi yang dikeluarkan pemerintah melalui Bagian Hukum. Dalam Perda Kota Yogyakarta No. 1 Tahun 2012 tentang Pengelolaan Lingkungan Hidup Kota Yogyakarta dinyatakan, bahwa pencegahan pencemaran, perusakan dan kerusakan lingkungan hidup dilakukan melalui pengelolaan dan penanganan limbah (termasuk B3) yang izinnya diberikan oleh Walikota (atau pejabat yang ditunjuk sesuai kewenangannya), pengelolaan air tanah (izinnya dari Walikota), pengendalian pencemaran udara, ruang terbuka hijau, pengeloaan sampah dan baku mutu lingkungan. Sementara itu mengenai perizinan diatur tersendiri.

Ada Izin Lingkungan yang mensyaratkan adanya dokumen AMDAL dan UKL-UPL. SPPL disebutkan juga sebagai syarat di samping kedua dokumen itu. Yang menarik ialah penyebutan "jenisjenis izin lingkungan”, yaitu Izin Penyimpanan dan Pengumpulan Sementara limbah B3, Izin Pembuangan Limbah Cair, Izin Pengambilan dan Pemanfaatan Air Tanah dan izin lingkungan lainnya berdasarkan peraturan perundangan yang berlaku. Semua izin ini ditetapkan dengan Keputusan Walikota. Sebetulnya dalam UUPPLH disebutkan Izin Lingkungan sebagai "nama dari izin" dan menujuk pada izin tersendiri, yaitu "Izin Lingkungan.” Dalam Perda izin-izin tersebut adalah “jenis dari izin lingkungan.” Maksudnya ialah, bahwa izin-izin itu berkaitan dengan lingkungan hidup, bukan Izin Lingkungan, sebab Izin Lingkungan diberikan setelah AMDAL, UKL-UPL dan keputusan kelayakan lingkungan.

Di samping izin-izin tersebut ada pula izin penting yang berkaitan dengan lingkungan hidup, yaitu Izin Gangguan sebagaimana diatur dalam Perda Kota Yogyakarta No. 2 Tahun 2005 tentang Izin Gangguan. Salah satu syarat pengajuan izin ini adalah adanya dokumen pengelolaan lingkungan hidup (Pasal 7 ayat (1) huruf b). Dokumen ini tentu saja terdiri dari AMDAL, UKL-UPL (bagi kegiatan yang diwajibkan untuk itu) dan SPPL. Adanya syarat ini sebenarnya jelas berkaitan dengan upaya pencegahan pencemaran, perusakan dan kerusakan lingkungan hidup di wilayah Kota Yogyakarta. Ini juga berarti, bahwa Pemkot secara hukum memiliki perhatian bagi pelestarian fungsi lingkungan hidup di wilayah ini.

Mengenai pelaksanaan perizinan di Kota Yogyakarta secara singkat adalah sebagai berikut. Pertama, Pemerintah Kota melalui Bappeda melihat kepentingan lingkungan hidup tidak hanya semata-mata demi lingkungan hidup itu sendiri melainkan juga berkaitan dengan kepentingan seluruh masyarakat. Hal ini dituangkan juga dalam KLHS. Menyangkut kepentingan lingkungan hidup, ada kebijakan evaluasi yang dilakukan oleh Pemerintah Provinsi dengan melibatkan seluruh unsur dari Kabupaten dan Kota. Ini berarti bahwa pertimbangan pemberian izin juga dilihat dari segi kehidupan masyarakat sendiri, seperti bagi dunia usaha. Meskipun demikian, Pemkot juga tidak mengabaikan kepentingan lingkungan hidup. Pembangunan hotel-hotel misalnya dikendalikan dengan Peraturan Walikota No. 77 Tahun 2013.

Kedua, Salah satu instansi pemerintah yang berwenang mengeluarkan izin di bidang lingkungan hidup adalah Badan Lingkungan Hidup Kota. Badan teknis ini boleh dikatakan sebagai "ujung tombak" pemerintah dalam bidang penyelamatan lingkungan hidup. Berkaitan dengan Izin Lingkungan, diberikan BLH sesuai dengan ketentuan yang berlaku. Izin Lingkungan dikeluarkan setelah adanya AMDAL, UKL-UPL dan keputusan kelayakan lingkungan. Bahkan di BLH ini telah ada Komisi PenilaiAMDAL yang di kabupaten-kabupaten lain belum ada. Bagi kegiatan atau usaha yang tidak membutuhkan Izin Lingkungan, diwajibkan adanya SPPL (Surat Pernyataan Pengelolaan Lingkungan Hidup) yang menurut BLH selalu ditangani pengurusan dan pengawasannya, sehingga tidak ada pelanggaran atau penyimpangan. 
Ada beberapa jenis izin yang ditangani oleh BLH selain Izin Lingkungan seperti Izin Penyimpanan B3 yang diatur dalam Peraturan Walikota No. 57 Tahun 2010, Izin Pembuangan Limbah Cair dalam Peraturan Walikota No. 9 Tahun 2014 tentang Izin Pembuangan Limbah Cair dan Pemanfaatan Limbah Cair. Izin Pemanfaatan Air Tanah telah diambilalih oleh provinsi sejak diberlakukannya UU No. 23 Tahun 2014 tentang Pemda. Dalam mengeluarkan izin-izin tersebut BLH berpegang teguh pada aturan yang berlaku. Sementara itu, kebijakan perizinan yang diambil Pemkot terkait perizinan lingkungan sebetulnya sama dengan dua kabupaten lain, yaitu menjadikan Izin Lingkungan sebagai syarat pemberian IMB dan HO. Hanya saja Pemkot mengambil kebijakan "baru", yaitu adanya AMDAL lalu lintas yang ditujukan terutama bagi perluasan hotel. Menurut Pemkot, pembangunan hotel baru "tidak diizinkan lagi”. Yang diizinkan adalah perluasan hotel dengan syarat adanya AMDAL lalu litas tersebut. Meskipun tidak terkait langsung dengan pencemaran lingkungan, kebijakan ini boleh dikatakan sebagai bagian dari pelestarian fungsi lingkungan hidup.

\section{Kesimpulan}

Berdasarkan hasil penelitian ini, dapat diambil kesimpulan, bahwa meskipun kondisi lingkungan hidup di Kabupaten Sleman, Bantul dan Kota Yogyakarta masih tergolong "baik", tetap diakui adanya tekanan atau ancaman terhadap kelestarian fungsi lingkungan hidup berupa pencemaran, perusakan dan kerusakan lingkungan hidup. Salah satu instrumen untuk mencegah permasalahan itu adalah perizinan lingkungan. Pemerintah di masingmasing daerah tersebut pertama-tama berpedoman pada peraturan perundang-undangan, khususnya Perda, Perbup, dan Perwal dalam menetapkan perizinan lingkungan. Kebijakan yang diambil memang sesuai dengan aturan, namun daerahdaerah menetapkan sendiri kebijakan perizinan seperti Izin Lingkungan dikaitkan dengan $\mathrm{HO}$ dan IMB, muatan lokal dan pertimbangan harmoni kepentingan pelestarian fungsi lingkungan hidup dan dunia usaha.

\section{DAFTAR PUSTAKA}

\section{A. Buku}

Dye, Thomas, R. 1978, UnderstandingPublic Policy, Prencite Hall Inc., New York.

Edward III, George, C \& Ira Sharkansky, 1978, The PolicyPredicamment, W.H. Freeman and Company, San Farncisco.

Fajar,Mukti dan Achmad, Yulianto, 2010, Dualisme

Penelitian Hukum Normatif \& Empiris, Pustaka Pelajar, Yogyakarta.

Glasson, John, et al., 1994, Introduction to Environmental Impact Assessment $\quad\left(3^{\text {rd }}\right.$ Edition), UCL Press, London.

Islamy, M. Irfan, 1992, Prinsip-Prinsip Perumusan Kebijaksanaan Negara, Bumi Aksara, Jakarta.

Kloepfer, Michael, 1989, Umweltrecht, C.H. Beck'sche Verlagsbuchhandlung, München. Lasswell, Harold, D \& A. Kaplan, 1970, Power andsociety, YaleUniversity Press, New Haven.

Muhjad, Hadin H.M. 2015, Hukum Lingkungan. Sebuah Pengantar untuk Konteks Indonesia, Genta Publishing, Yogyakarta.

Pudyatmoko,Y. Sri, 2009, Perizinan problem dan upaya pembenahan, Grasindo, Jakarta.

Rahmadi,Takdir, 2011, Hukum Lingkungan di Indonesia, RajaGrafindo Persada, Jakarta.

Schmidt, Reiner, 1992, Einführungin das Umweltrecht (Pengantar Hukum Lingkungan), VerlagC.H.Beck, München.

Spelt, N. M \&J.B.J.MtenBerge, 1993, Pengantar Hukum Perizinan, Penerbit Yuridika, Surabaya.

Susanto, Anthon, 2011, Penelitian Hukum Transformatif-Partisipatoris, Lo Goz Publishing, Bandung. 
Portland House, 1990, Webster's Desk Dictionary of the English Languange, Random House Value Publishing, New York.

\section{B. Hasil Penelitian}

Rangkuti,Siti Sundari, 1987, Hukum Lingkungan dan Kebijakan Lingkungan Dalam Proses Pembangunan Nasional Indonesia, Disertasi, Program Doktor, Fakultas Hukum Universitas Airlangga, Surabaya.

\section{Peraturan Perundang-undangan}

Undang-Undang No. 23 Tahun 1997 tentang Pelestarian Lingkungan Hidup (Lembaran Negara Republik Indonesia Tahun 1997 No. 68, Tambahan Lembaran Negara Republik Indonesia No. 3699).

Undang-Undang No. 32 Tahun 2009 tentang Perlindungan dan Pengelolaan Lingkungan Hidup (Lembaran Negara Republik Indonesia Tahun 2009 No. 140, Tambahan Lembaran Negara Republik Indonesia No. 5059).

Undang-Undang No. 23 Tahun 2014 tentang Pemerintahan Daerah (Lembaran Negara Republik Indonesia Tahun 2014 No. 244, Tambahan Lembaran Negara Republik Indonesia No. 5587).

Peraturan Pemerintah No. 27 Tahun 2012 tentang Izin Lingkungan (Lembaran Negara Republik Indonesia Tahun 2012 No. 48,Tambahan Lembaran Negara Republik Indonesia No. 4285).

Peraturan Menteri Lingkungan Hidup No. 13 Tahun 2010 tentang Upaya Pengelolaan Lingkungan, Upaya Pelestarian Lingkungan, dan Surat Pernyataan Pengelolaan Lingkungan.

Peraturan Menteri Lingkungan Hidup No. 5 Tahun 2012 tentang Kegitan yang Wajib Analisis Dampak Lingkungan.

Peraturan Gubernur Daerah Istimewa Yogyakarta No. 7 Tahun 2010 tentang Baku Mutu Limbah Cair Bagi Kegiatan Industri, Pelayanan Kesehatan, dan Jasa Pariwisata.

Peraturan Daerah Kota Yogyakarta No. 2 Tahun
2005 tentang Izin Gangguan (Lembaran Daerah Kota Yogyakarta No. 65 Seri D).

Peraturan Daerah Kabupaten Bantul No. 4 Tahun 2011 tentang Rencana Tata Ruang Wilayah (Lembaran Daerah Kabupaten Bantul Tahun 2011 No. 04 Seri C).

Peraturan Daerah Kota Yogyakarta No. 1 Tahun 2012 tentang Pengelolaan Lingkungan Hidup Kota Yogyakarta (Lembaran Daerah Kota Yogyakarta No. 1).

Peraturan Daerah Kabupaten Sleman No. 12 Tahun 2012 tentang Rencana Tata Ruang Wilayah Kabupaten Sleman Tahun 2011-2031 (Lembaran Daerah Tahun 2012 No. 1 Seri E). Peraturan Daerah Kabupaten Sleman No. 5 Tahun 2014 tentang Izin Gangguan (Lembaran Daerah Tahun 2014 No. 1 Seri B).

Peraturan Gubernur D.I. Yogyakarta No. 20 Tahun 2008 tentang Baku Mutu Air (Ambien) di Daerah Istimewa Yogyakarta.

Peraturan Walikota Yogyakarta No. 57 Tahun 2010 tentang Izin Penyimpanan Sementara dan Pengumpulan Limbah Bahan Berbahaya dan Beracun.

Peraturan Bupati Bantul No. 18 Tahun 2012 tentang Upaya Pengelolaan Lingkungan Hidup dan Upaya Pemantauan Lingkungan Hidup dan Surat Pernyataan Kesanggupan Pengelolaan dan Pemantauan Lingkungan Hidup.

Peraturan Walikota Yogyakarta No. 9 Tahun 2014 tentang Izin Pembuangan Limbah Cair dan Pemanfaatan Limbah Cair.

Peraturan Bupati Bantul No. 9 Tahun 2014 tentang Izin Gangguan.

Peraturan Bupati Sleman No. 24 Tahun 2014 tentang Kewenangan Penyelenggaraan Perizinan.

Peraturan Bupati Bantul No. 46 Tahun 2014 tentang Izin Lingkungan.

Peraturan Bupati Bantul No. 20 Tahun 2015 tentang Izin Gangguan.

Peraturan Menteri Lingkungan Hidup No. 9 Tahun 2011 tentang Pedoman Umum Kajian Lingkungan Hidup Strategis. 